\title{
Does democratization process lead to positive environmental public policies in the Colombian case?
}

\author{
Carolina Velandia Hernández ${ }^{\dagger}$ Northern Illinois University ${ }^{1}$
}

\begin{abstract}
Does democratization process lead to positive environmental public policies in the Colombian case? By focusing on variations in authoritarianism and democratic rule during the 1990s, this paper tests the hypothesis that an increase in democratic rule produces changes to environmental protection along two levels, legal framework and institutional accountability. The dependent variables are democratization and authoritarianism. The independent variable is the level of environmental protection in the public policy outcome. The qualitative analysis is focused on the factors and causal mechanism that allows to evaluate the hypothesis. The findings are that the periods of authoritarian rule and democratic rule are highly influenced by two factors. The first is domestic (postcolonial institutions, regime's organizational strength, elites' cleavages, revolutionary and counterrevolutionary movements, and the strength of environmental movement) and second international (western linkage and international organizations' influence). The Colombian case in the 1990s allows for an identification of these different characteristics of authoritarian and democratic regimes and the causal mechanisms that promote or avoid environmental protection.

Keywords: democratization, Colombia, authoritarianism, environmental policies, environmental protection.
\end{abstract}

\section{Introduction}

The present research process focuses on the1990s where the implementation process on environmental policy was successful at the legal and institutional level. These analyses will not consider the effectiveness of this policy. This paper considers in the analysis the principal debate over how to categorize Colombia as either an authoritarian regime or democracy. However, the 1990s will be considered as the starting point of an effective democratization process.

\footnotetext{
${ }^{\dagger}$ Preliminary Draft. Please do not cite or circulate without author's permission. Working paper 2020.

1 PhD student in the Political Science and Public Administration department.
} 
There is a possible causal path between the democratization process in Colombia and the environmental protection in its public policy. Therefore, the question is whether the democratization process in Colombia actually improved environmental public policies during the 1990s. The hypothesis is that an increase in democratic rule produces positive changes that improve environmental protection along two levels, legal framework and institutional accountability.

Democratization can lead to more protection than authoritarianism. The qualitative method allows an evaluation between Colombian authoritarianism and democracy. Factors or attributes of democratic and authoritarian regimes that increase or promote a protection of the environment will be identified by the dynamic between regime characteristics, the actors involved in the decisionmaking process, and the outcomes at the legal and institutional level. For example, while the research started with the assumption that the democratic regime dynamic will include protected areas, species, and social protection to indigenous populations and their habitats, it also will allow the participation of both environmental movements and green parties, and promotes human safety by protecting the environment. Therefore, historical institutional analysis will provide evidence that should be found in the policy outcome.

The findings are that an increase of democratization process has a positive influence in the environmental protection. Under certain conditions of internal and external factors, it is more likely that a positive change in the policy outcome that leads to an increase of environmental protection can be produced. The cross-time analysis provides evidence that the change of policy outcomes, legal and institutional environmental policy structure, is caused by the level of democratization or authoritarianism.

The present research contributes to first, the theoretical debate of competitive authoritarianism and contentious politics apply to Latin-American complex cases. Second, it integrates a political science methodological and theoretical framework with International Relations (IR) theory and public administration. The conclusion is that more research must be done with mixed methods that allows for analysis of data to measure the impact of democracy in public policy outcomes with a focus on common goods as environmental or energy resourses.

\section{Literature review}

The literature can be classified in three levels. First, the debates that identify the relationship between authoritarianism or democracy and environmental protection (Heilbroner, 1974; Ophuls, 1977; Dryzek, 1987; Grossman \& Krueger, 1991; Webster, 1993; Beckerman, 1992; Paehlke, 1995, 1996; Taylor,1996; Desai, 1998; Midlarsky, 1998; Didia, 1997, Bhattarai and Hammig, 2001; Smith, 
2003; Winslow, 2004; Farzin and Bond, 2006; Li and Reuveny, 2006; Carter, 2018). Second, the big debates that categorized what factors distinguish authoritarianism from democracy (Dahl, 1971; Linz, 1975; O'Donnell, 1978; Remmer \& Merkx, 1982; Geddes, 2003; Brooker, 2000; Wahman, Teorell \& Hadenius, 2013, Schmitter \& Karl, 1991; Collier \& Levitsky, 1997; Zakaria; 1997); and third, studies of the Colombian democratization process (Cohen, 1985; Bejarano, 2011; Wills-Otero, 2015; Hartlyn, 1984; Mainwaring \& Pérez-Liñán, 2013; Acuña, 2006; Londoño, 2009; Stevens, Bishin \& Barr, 2006).

This literature focuses on the framework that will be used to study the case. I will not develop the complete debate among democratization processes and their causes, or the theoretical and methodological aspect of the differences between authoritarian and democratic regimes, because it is not the scope of this research. I will identify in this literature first, the recent evolution of the question of how democracy improves environmental protection; second, which concept of authoritarianism and democracy will be used in this research; and third, the construction of the method based on the theories of Steven Levitsky and Lucan Way, Competitive Authoritarianism, and Dan Slater, Contentious Politics and Authoritarian Leviathans.

\section{The regime hypothesis: Democracy improves environment protection.}

The question of whether or not democracy improves the environmental protection has been the subject of academic debate. The first argument is that democracy creates conditions which allow the inclusion and improvement of environmental public policy. It argues within regimes there exists a correlation between democracy and environmental quality (Grossman \& Krueger, 1991; Beckerman, 1992).

The regime hypothesis suggests that democratic regimes include environmental debate, the common goods management such as environmental quality, and coordination of the action of public administration and non-state actors. The last one at the local, national, regional and international level to promote environmental protection. This argument also includes the rule making process, enforcement of environmental law, the size of the state, the relation with corruption, and the local level of democratization. Scholars in favor of this argument establish democratic regimes that are more likely to made decisions in favor of the environment.

The relation of democratic regimes and environmental protection has been evaluated based on the increase of protection to environmental quality, response to the level of scarcity of resources, and environmental degradation or pollution. The first group of literature evaluates the correlation among democracy and environmental protection quality (Dryzek, 1987; Paehlke, 1995, 1996). The evaluation of this relation can be done by the increase of civil participation and creation of networks, 
for instance, the environmental movement involvement in public policy and its institutionalization through green parties (Doyle and McEachern, 1998; Van Der Heijden,1997). The literature also develops the argument that authoritarian regimes do not help environmental movements (Taylor,1996) and under certain circumstances democracy does not respond to scarcity of resources, degradation, and prevention (Heilbroner, 1974; Ophuls, 1977).

The second line of the literature has focused on why democratic regimes are more likely to protect the environment than authoritarian regimes. Scholars studied the benefits of pollution for some interest groups and the pollution consequences as a collective action problem spread on the entire society. The basic argument is that a democratic regime by sharing power can decrease the negative impacts of pollution. Also, democratic regimes have an increase in accountability that can stop leaders to get profit from the environmental degradation. New actors in the policy making process increase civil society participation. Also, democracy permits global access to information which allows for the identification and resolving of environmental problems, and the nongovernmental actors lobbying promotes environment causes. In a democratic regime, it's supposed to exist litigation tools and legitim mechanism that enforce environmental protection (Cohen, 2006; Winslow, 2004).

At the IR theory framework, there is an intersection in the literature that considers cooperation amongst the international system and democracies. This cooperation promotes international environmental agreements and a global regulatory framework (Doyle, 2005). IR theory also inquires on the double flow of domestic and international levels. Bernauer, Kalbhenn, Koubi and Spilker (2010) claim that the extent of the linkages of countries with the external environment affect global governance dynamics in comparison with the domestic internal factors. They proposed a conceptualization of the linkages in terms of the involvement in international organizations, integration in the world economy, and contingent behavior.

The method in the literature that measures the effect of democracy in the improvement of environmental public policy is mostly quantitative and looks for indicators to highlight the correlation. For instance, Shafik and Bandyopadhyay (1992) and Shafik's (1994) work measures regime quality by using environmental quality indicators. Their variables are level of investment, energy prices, debt level, trade policy, civil liberties, and political freedom following the Freedom House Index. Their findings are that the freedom house index only influences the levels of dissolved oxygen in rivers, environmental quality, and urban SO2.

The measurement of democracy and environmental degradation had been the principal focus of Midlarsky (1998). His findings are that there is a negative correlation effect of democracy on 
deforestation, $\mathrm{CO} 2$ emissions, and soil erosion by water. The positive correlation was with protected land areas. Considering the impact on special areas like tropical ones, the work of Didia (1997) studies the correlation of deforestation and democracy. He finds a strong negative correlation, meaning more democratic countries have a lower deforestation rates. Similarly, the work of Bhattarai and Hammig (2001) evaluates the relation of annual deforestation rates and a set of independent variables that includes political institutions measured by the Freedom House Index, and GDP on Latin America, Africa, and Asia. Webster (1993) and Desai (1998) evaluate the authoritarian record in environmental protection by contrasting it with democracies.

Winslow (2005) correlates the types of urban air pollution and by using the indices of democracy of Freedom House Index and Polity III. The experimental design made a regression analysis exploring urban air concentrations of three pollutants; sulfur dioxide (SO2), suspended particulate matter (SPM), and smoke. The findings show a possible relationship between environmental quality and democracy. The more democratic a country, the less urban air pollution. Even the environmental quality is not homogeneous, the air urban pollution measure provides insight on the emissions and not in the externalities shared by international community. The authors suggest that the measure of democracy quality is not homogeneous; different characteristics of a democratic regime can influence the level or quality of environmental protection.

More recent work was Farzin and Bond's (2006) publication that develops an econometric model analyzing the relation with local and global air pollutants and critical socio-political and economic aspects of the state's regime. Their findings are a "that democracy and its associated freedoms provide the conduit through which agents can exercise their preferences for environmental quality more effectively than under an autocratic regime, thus leading to decreased concentrations or emissions of pollution" (p. 233). The authors suggest that more research must be done on the extent of the linkage of the mechanism of a preferred environmental policy in democracies.

$\mathrm{Li}$ and Reuveny (2006) contribute on the causal mechanism to determine if democracy reduces environmental degradation or not. The causal mechanism which democracy affects is examined statistically on five aspects of human impact. For instance, carbon dioxide emissions, nitrogen dioxide emissions, deforestation, land degradation, and organic pollution in water. Their finding is that democracy reduces the environmental degradation.

In the same line, Smith (2003) presents a theoretical approach that questions if liberal democracies in terms of the extension of representation of new actors -environmental movement, changes values to include environmental ones. The scholar identifies that the decision-making process shows a conflictive relation of environmental values within a political decision-making 
process. The relevant contribution is the institutional answer that aggregates individual preferences in a collective choice that incorporates environmental cost and benefits.

To summarize, there are strong arguments about the correlation of democracy and its positive impact in environmental protection. However, in the Colombian case, this research requires clarification about the characteristics that distinguish democracy and authoritarian regime and how they can be applied to the selected period.

\section{Concept of authoritarianism and democracy application to Colombian case}

The scholars that identify pure authoritarianism suggest as principal characteristics the suppression of civil rights, the repression of opposition, a strong cleavage among elites and state capacity -economic, political, intellectual or religious-; this implies that the bureaucratic force makes the regime stronger (Brooker, 2000). Another approach considers authoritarian regime focused on leadership, whether the leader is a determined person, a unitarian party or parties, or military that control the political system, and particular bureaucratic authoritarianism (Geddes, 2003; O'Donnell,1978). Other classifications of authoritarianism consider regimes with fake elections and when the state is controlled by groups of interest (Collier and Steven Levitsky,1997; Levitsky and Way's, 2002).

The concept of authoritarianism is based on the absence of one or a set of characteristics that define a developed or consolidated democracy. In that sense both concepts are antagonist authoritarianism in one extreme and democracy in the other. Therefore, the democratization process is the process through which a country transits from authoritarianism by the stages that lead to a fully developed democracy. According with Brooker (2000), the characteristics proposed by Friedrich and Brzezinski's of an authoritarian regime are: 1) ideology; 2) single party typically individual-led; 3) terroristic police; 4) communications monopoly; 5) weapons monopoly; and 6) centrally-directed economy.

The Geddes's definition of authoritarianism (2003) includes possible typologies such as personalist, military, or single-party. This characterization is based on the influence on policy, electoral process, and leadership. Brooker (2000) identified that the key factor that allows for control in authoritarian regimes is the institutional structure going against a unique explanation based on ideology proposed by Linz (1975). The debate was rebutted by O'Donnell's theory $(1978,1994)$ that proposed Bureaucratic Authoritarianism regimes explains, far from Western version of democracy in developed countries, that the interception of theocratic and civilian elites produce a high degree 
of vertical integration. Cheibub (2010) distinguished the following categories: multiparty authoritarian, one-party authoritarian, no-party authoritarian and hybrids.

Levitsky and Way's (2002) explanation of modern democratic regimes present four criteria: 1) Executives and legislatives chosen by free, fair and open elections; 2) all adults had right to vote; 3 ) political rights and civil liberties are protected; and 4) elected authorities had a real authority to govern. Consequently, authoritarianism can be any hybrid, that survives mixing some democratic elements such as elections with authoritarianism.

In 2010, the same scholars refined their theory and proposed a new type of authoritarian regime with mixed characteristics. They conceptualized it as "competitive authoritarianism" (Levitsky \&Way, 2010). It refers to regimes that allow the opposition to utilize democratic institutions (i.e. elections) to contest for power, but they are not democratic because the level of playing field extensively leans toward incumbents. Competition in this regime is "real but not fair" (p. 5). Competitive regimes are not "incomplete, partial or inconsolidated democracy" because although some of them become democratized, many of them become stable or even become increasingly authoritarian.

Therefore, the question is when do authoritarian regimes democratize? For the scholars the answer lies in three variables: Western leverage, linkage to the West, and regime's organizational strength. "When there is high Western leverage on a competitive authoritarian, or in order words, when a competitive authoritarian regime is vulnerable to external democratizing pressure from the West because 1) Its size and economy is small, 2) It is not a strategic partner with the West, or 3) There is no support from a "black knight", therefore the regime is more likely to democratize. As a result of such vulnerability, the West can impose punitive sanctions, diplomatic pressures, and military intervention on the regimes. However, Western leverage is necessary but not enough condition for full democratization because the regime can adopt the electoral performance and ignore other democratic elements such as respecting civil liberties. Also, because the cost to monitor and enforce the conditionality is too high, the regime is left with enough room to maneuver and get away with just holding elections" (Ong \& Velandia, 2018).

"Linkage is defined as the density of economic, political, diplomatic, social, and organizational ties and cross-border flows of capital, goods, service, people, and information between a country and the Western world including the US, EU, and Western multilateral organizations. The linkage can be in the form of economic, intergovernmental, technocratic influences, information, and civil-society flows. Nevertheless, the most important linkage is geographical proximity. Because high linkage 
means the West can easily monitor and enforce leverage on the regime, the regime is less likely to employ electoral fraud and repression against the opposition" (Ong \& Velandia, 2018).

The second theory that can be used to explains which are the factors of authoritarian regimes that can lead to not environmental protection and builds the model of this research is the argument of Slater (2010). He argues that "Contemporary divergence in the elite coalitions underpinning postcolonial state and regime institutions has been primarily produced by historically divergent patterns of contentious politics. Broadly conceived as nonroutine political events involving considerable popular mobilization, contentious politics encompasses a wide range of transgressive, collective mass actions - from labor strikes to ethnic riots, from rural rebellions to student protests, from urban terrorism to street barricades, and from social revolutions to separatist insurgencies. While such plasticity in a concept can often be an analytic weakness, contentious politics proves quite useful as an umbrella term capturing the diverse types of internal conflict that have characterized and- as I shall argue and attempt to demonstrate shaped the postcolonial world." (p. 5) The elements of contentious politics, pot colonialism and elites are included in the model to analyze the case.

The case of Venezuela and Colombia had been deeply studied by Ana Maria Bejarano. Her publications Precarious Democracies (2011) and Political reform after 1991 (Pizarro and Bejarado, 2007) integrates historical institutionalism with the democracy theory. Bejarano identified as key attributes for democracy: 1. Inclusion of the majority of adult population through universal suffrage 2. Selection of the top political leaders by means regular competitive, free, fair elections, 3 . Respect and effective protection of civil rights and liberties, 4 . Ability of elected authorities to govern.

By using a comparative historical institutional approach, the findings of the author explained a different path to democracy that in Colombian case is not only the economic dependence to coffee or drugs dependence, it started with the historical conditions to the formation of the state and the parties' system. This influence in the deep kind of democracy depending of factors as the range of actors included in the institutional agreements, the nature and scope of the restrictions imposed on subsequent political interaction and the degree to which these restrictions become entrenched in constitutional provisions. Therefore, the democracies crisis is a reflect of the erosion and decay of the political parties and the state. The argument of the book is a theoretical proposal beyond the debate of democratic consolidation and the quality of democracy. The argument is built in the notion of institutionalization as the post transition development into a stable regime that is able to fulfill and reproduce the procedural conditions for political democracy. 


\section{The puzzle and the model.}

The puzzle is focused on the question: does democratization process lead to positive environmental public policies in the Colombian case?. The hypothesis is that increase in democratic rule produces changes that improve environmental protection in two levels, legal framework and insitucional accountability. Based on the theories, competitive authoritarianism and contentious politics, the following model will be evaluated by a qualitative method based on historical institutional analysis. The theoretical framework used in this research is shown in Figure 1.

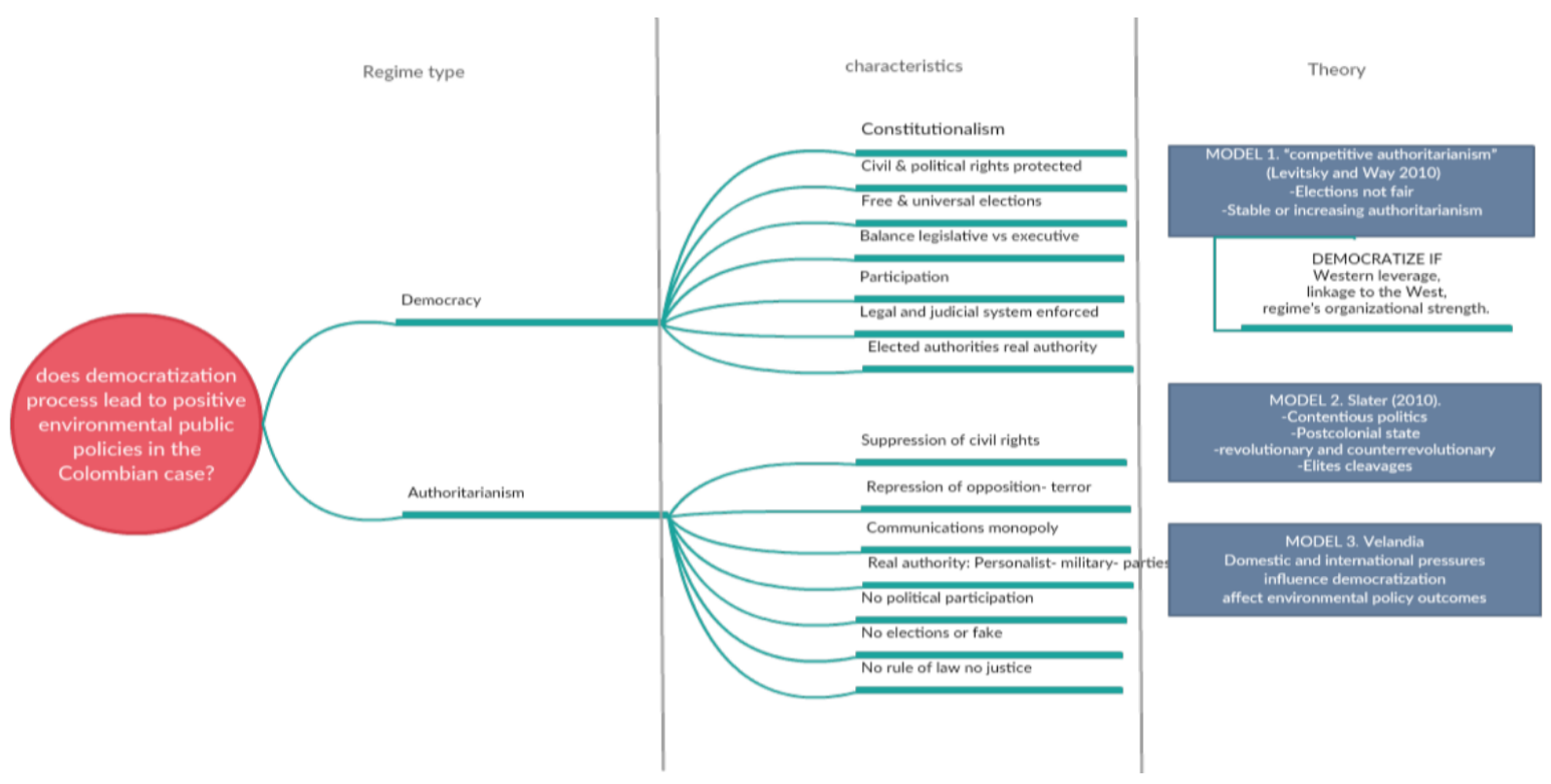

Figure 1. Regime type argument. (Velandia, 2018) 


\section{Method}

Figure 2 describes the method followed in the research.

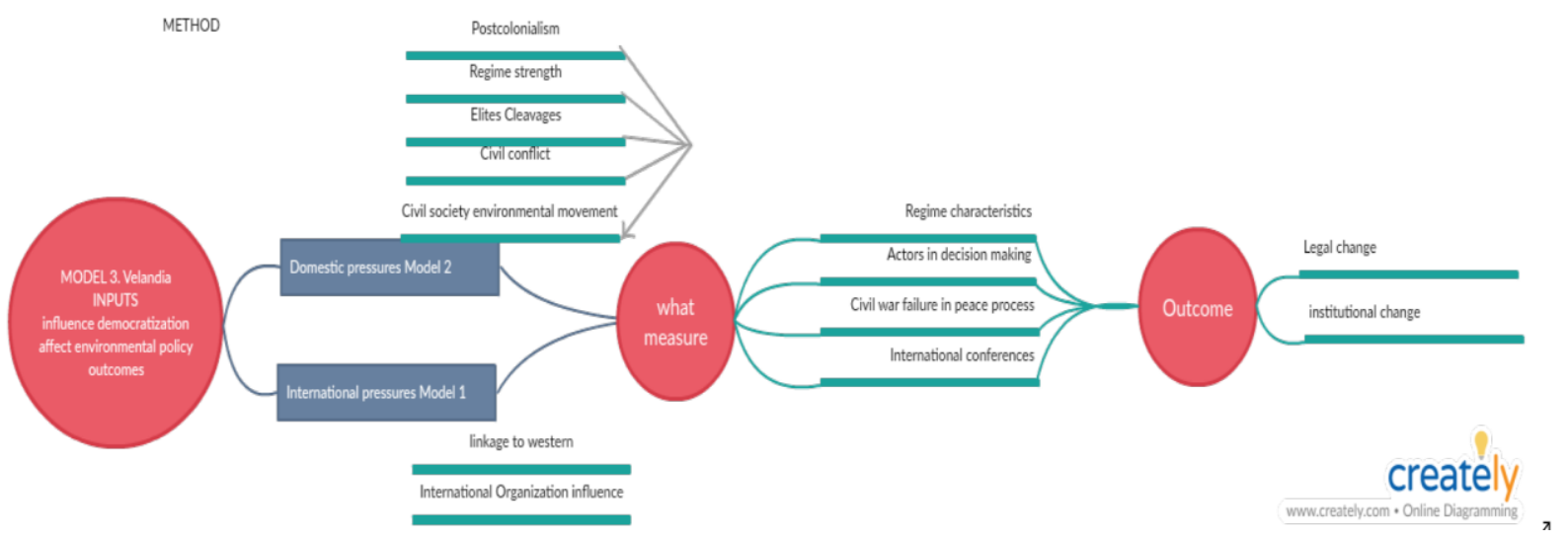

Figure 2. (Velandia, 2018)

To answer the research question, it is required to develop a causal pathway. To do it, the research evolved in the following causal steps. First, the starting point is authoritarianism in Colombia that led to a negative policy outcome in environmental protection. During the 1970's, some structural rules of environmental protection was produced (Resources Code of 1972), that indicated the personalist power of the president more than the growing influence of social movement towards environmental protection.

Second, following the model proposed, the domestic and international pressures were analyzed in the 1990s, this identified the attributes to democracy that led to an increase in environmental protection. The elements studied as domestic pressure are relevant post-colonialist characteristics, the regime factors (parties system, electoral system, relation among executive and legislative), the elites cleavages, the civil conflict intensity. The domestic pressures influence the civil society participation, implying it affects the performance of environmental movement, leading it to an institutionalization thought the party system or constitutionalizing of the environmental rights and litigations tools.

Third, the casual mechanism was measured by considering two levels, domestic and international influences in: the regime characteristics, the influence of actors in the decision-making process, the civil war meaning the failure in several peace processes, and the influence of international community through Colombia participation in international environmental conferences. The fourth step evaluated the outcomes. The research will identify which were the legal and institutional changes. 


\section{Case analysis and historical institutional analysis.}

The casual mechanism measured consider the domestic and international influences. The elements chosen will be described in Table 1.

Table 1. Colombian case 1990s.

\section{Democracy}

Periods. Authoritarianism previous to 1990.

Decade 1990. Relevant historical facts:

- Three presidential candidates were killed by different armed forces. As a result, Cesar Gaviria T. was elected in 1990 as president.

- Increase of violence between the drug cartels: Dismantling of the Medellin Cartel with the death of Pablo Escobar in 1993. Dismantling of the cartel of Cali in1995 and La Costa in 1998.

- End of the peace process with the Guerrilla M-19 (April 19 Movement).

- Demobilization of 95\% of the EPL (Liberation Popular Army) guerrilla group in 1991.

- Demobilization of the guerrilla groups that made up the CGSB (MAQL, the PRT and the CRS) in 1991.

- Promulgation of the new Constitution in 1991.

- Electoral reform, political reform, economic reform.

- Implementation of the structural reforms suggested by multilateral organizations.

- Break up of negotiations with FARC (Armed Forces revolutionary of Colombia) guerrilla in 1994.

- New intent of negotiation under presidency of Andres Pastrana in 1998.

- $\quad$ Spread of paramilitaries AUC (Autodefense United of Colombia).

IV1. Regime characteristics

\begin{tabular}{|c|c|}
\hline $\begin{array}{l}\text { Party } \\
\text { composition }\end{array}$ & $\begin{array}{l}\text { - From traditional two-party system to a multi-party system. } \\
\text { - } \quad \text { Political reform. } \\
\text { - } \quad \text { Constitutional reform. }\end{array}$ \\
\hline Elections & $\begin{array}{l}\text { - } \quad \text { Reform: based on list system and d'Hondt method. } \\
\text { - Special electoral protections for indigenous, afro-Colombians, } \\
\text { and women. } \\
\text { - } \quad \text { Decentralization, direct elections at the local level. }\end{array}$ \\
\hline Civil rights & $\begin{array}{l}\text { - Constitutional inclusion of rights of first, second, and third } \\
\text { generation (Civil, political, economic, and groups rights). } \\
\text { - Inclusion of environmental rights. } \\
\text { - Inclusion of environmental legal and environmental } \\
\text { constitutional actions as group, consumers actions, and } \\
\text { Constitutional action of protection "tutela". } \\
\text { - Creation of the constitutional tribunal of justice. }\end{array}$ \\
\hline Authority & $\begin{array}{l}\text { - Authority of central state diminish. } \\
\text { - Decentralization: political, administrative, and fiscal, allocate } \\
\text { authorities at local level. } \\
\text { - } \\
\text { Real control of territories by traditional elites, paramilitary and } \\
\text { guerrilla. } \\
\text { - Remain patronage and clientelist practices. }\end{array}$ \\
\hline
\end{tabular}




\begin{tabular}{|c|c|c|c|}
\hline \multirow[t]{5}{*}{$\begin{array}{l}\text { Domestic } \\
\text { pressures }\end{array}$} & $\begin{array}{l}\text { Executive- } \\
\text { legislative } \\
\text { dynamic. }\end{array}$ & \multicolumn{2}{|c|}{$\begin{array}{l}\text { - Presidential regime. } \\
\text { - Increase of control mechanism of the legislative to the executive. } \\
\text { - Tension in funding and technical support with Congress. }\end{array}$} \\
\hline & $\begin{array}{l}\text { Environmental } \\
\text { movement }\end{array}$ & \multicolumn{2}{|c|}{$\begin{array}{l}\text { - Inclusion of movements and parties in the political debate. } \\
\text { - Inclusion of environmentalist platforms in parties. }\end{array}$} \\
\hline & $\begin{array}{l}\text { Colonialism, } \\
\text { race and land }\end{array}$ & \multicolumn{2}{|c|}{$\begin{array}{l}\text { - Concentration of land ownership in traditional families that } \\
\text { came from colonial times. } \\
\text { - Poor political representation of afro-Colombians, indigenous } \\
\text { population and women. }\end{array}$} \\
\hline & $\begin{array}{l}\text { Actros in } \\
\text { decision making } \\
\text { process }\end{array}$ & $\begin{array}{l}\text { Elites } \\
\text { cleavages }\end{array}$ & $\begin{array}{l}\text { - Strong relation between economic and political } \\
\text { elites. } \\
\text { - The ANDI association of industrials had a strong } \\
\text { lobby with traditional parties. }\end{array}$ \\
\hline & Civil war & $\begin{array}{l}\text { Counter } \\
\text { revolutionary } \\
\text { movement }\end{array}$ & 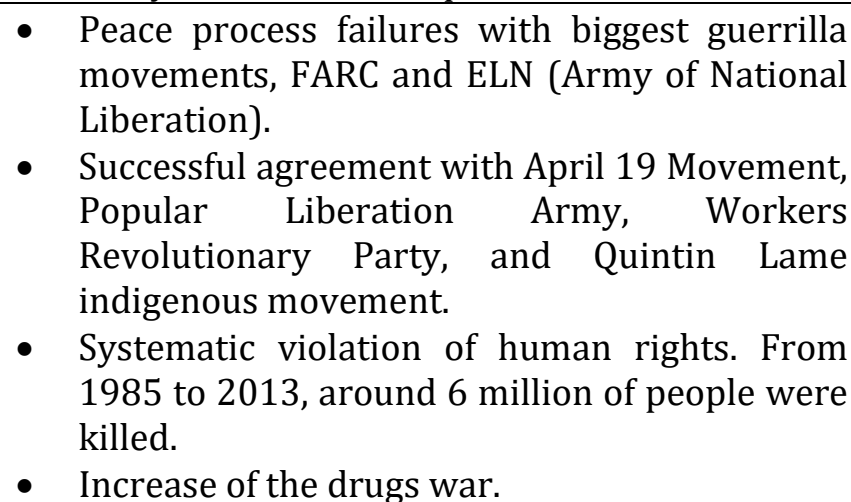 \\
\hline $\begin{array}{l}\text { International } \\
\text { pressures }\end{array}$ & $\begin{array}{l}\text { International } \\
\text { conferences, } \\
\text { agreements, } \\
\text { Western } \\
\text { linkages }\end{array}$ & $\begin{array}{l}\text { Agreements } \\
\text { or } \\
\text { participation } \\
\text { in } \\
\text { conferences }\end{array}$ & $\begin{array}{l}\text { - } \text { Rio conference } 1992 \text { impact. } \\
\text { - Creation of the National system of national } \\
\text { environment (SINA) } \\
\text { - New sources of funding. } \\
\text { - Influence by the international environmental } \\
\text { movement. }\end{array}$ \\
\hline
\end{tabular}

\section{Starting point: competitive authoritarianism in Colombia.}

Colombia democracy conducted elections since the Republican period (in 1810). The problem was focused on one hand, in the universalization of vote and on the other, the historical control of the traditional parties of the electoral system. The research started with the assumption that Colombia prior to the reforms in the 1990s, can be categorized as competitive authoritarianism, following Levitsky and Way (2010), because the democratic history it is compatible with some formal characteristics of democracy.

The constitutional and legal framework from 1950s to 1980s was looking for democratic institutions. Besides, part of the opposition was able to use constitutional channels to compete for power. However, the limitation of the theory, in the Colombian case, lacks the inclusion of two factors: the civil conflict and the spillover of narco-trafficker in the legal institutions. To develop this analysis, 
the characteristics that Levitsky and Way proposed to distinguish authoritarianism from competitive authoritarianism will be evaluated.

The first characteristic is competitive elections. Colombia was, until 80s, a civilian regime with a formal existence of democratic institutions established in the Constitution of 1886 . The origin of M-19 guerrilla was caused for the manipulation of the elections of Misael Pastrana, which were not free and altered by the traditional parties.

The second characteristic is full adult suffrage. The women suffrage was stablished by the military regime in 1954. There was a problem to measure the data of percentage of population that freely participate in the elections and how strong is the patronage. The scholars disagree about a formal universalization versus the effectiveness of election and the control of the local governments by the central state. Besides, in this decade the electoral debate was one of the motives that increase the internal armed conflict (Hartlyn,1984).

The third characteristic is broad protection of civil liberties, including freedom of speech, press, and association. These liberties where include in the Constitution of 1886 . However, the origin of the internal armed conflict was the violation of political rights, for instance, unions of workers, pedestrians, students, and other sectors did not have representation inside of the political and parties' system. During the 70s the first wave of global liberalization there were an increase of the armed conflict, this process was more intense in the rural areas and during the 80s because the conflict integrates new actors, such as the drug lords, already organized in a network of actors that creates alliances with traditional landowners and some economic elites (Bejarano and Leongómez, 2002).

The fourth characteristic is the absence of nonelected "tutelary" authorities (e.g., militaries, monarchies, or religious bodies) that limit elected officials' power to govern. The history of the internal conflict evidence the interrelation of parallel forces. For instance, the role of catholic church, part of military army that exercise terror against opposition or generate linkages with paramilitaries. Also, the economic, political, and industrial elites were related with financing paramilitaries. This lead to a polarization of the society that related social movements with left ideologies.

Levitsky and Way (2010) suggest that "Competitive authoritarian regimes are distinguished from full authoritarianism in that constitutional channels exist through which opposition groups compete in a meaningful way for executive power" (p. 27). This is the key factor. The constitution of 1886 and the progressive inclusion of Colombia in international agreements does not change the reality that just some actors were able to participate in the basic constitutional channels. Therefore, Colombia is an authoritarian not competitive authoritarian regime. 
Levitsky and Way defined Colombia as a "illiberal" electoral regimes. It is not a competitive authoritarianism because "in which mainstream parties compete on a reasonably level playing field but widespread human- or civil-rights abuse - often targeting nonmainstream political parties or ethnic groups - persist (e.g., Colombia and Sri Lanka in the early 1990s). Because violations do not directly affect mainstream political competition, such hybrid regimes are not competitive authoritarian". However, their analysis avoids the degree of influence of US foreign policy with the formal and informal elites in Colombia and a deep analysis of the institutional performance.

\section{Case study: Colombian democratization process in the 1990s decade.}

The general characterization of the decade concentrates in the liberalization period of the sub-region with the economic aperture, and the influence of the structural reforms on the domestic politics. However, the main domestic institutional transformation came from the constitutional change in 1991 because of groups of interest's negotiations for a change at the state and political system level.

The 90s decade had to overcome the National Front period's (1958-74) heritage. The norms of the 1980s created a deeper fragmentation in the traditional parties, affected negatively the political movements, and the political organizations. The political reform of 1990s is immersing in structural debates as the decline of the state central authority, the ongoing armed conflict where the negotiation lacks two of the principal guerrillas - FARC and ELN, and elites as counter revolutionary forces were pushing to stop the political reforms.

Nevertheless, the Constituent Assembly of 1991 produce three specific mechanism to increase representativeness. First, special electoral districts of ethnic minorities (indigenous and afro-Colombian communities), and the ex-insurgent groups. Also, at the end of the decade by the work of the Senator Piedad Cordoba was approved the law of quotas, referred to the inclusion of women in a $30 \%$ of the high-ranking position at all levels of governmental positions. Second, set of rules that allow participation to parties, political and social movements in the electoral process. Third, creation of a nationwide senatorial district that includes minorities in the election of senators —dispersed strategy (Botero, 1998). Title IV of the Constitution, referred to political participation and political parties, creates a basis of rights and obligations. Then, the Law 130 of 1994 regulated the political parties' conformation, the support and control by the state such as access to television and funding. The requisites for party creation diminished by some scholars that explained the party fragmentation. 
One of the critical changes was the implementation of the quotient and reminder formula (Hare system, that allocates seats proportionally for representative with a party list) and freedom of endorsement. The critics made to the reform was that the elected legislators do not have obligation to be accountable, the list or remainder formula do not control the funds, or not create a central party treasure control. Therefore, the legislators funding includes armed groups — right and left- and narco-trafficker. Other negative effect of the party fragmentation, according to Bejarano (2011) and Pizarro and Bejarano (2007), is on the opposition consolidation to control over the expenses and performance of the government.

The evaluation of the multiparty system was made by the Commission of Party Reform in 1995 and by an expert report named Valenzuela et al. (1999). The debates about the political reform includes the following critical aspects: 1) electoral reforms; 2) internal party democratization; 3) the opposition's right and obligations; 4) reforming Congress; and 5) campaign and party financing. In my analysis this correspond to the measurement of the regime characteristics, the participation of actors in the decision-making process, the civil war and the influence of international pressures that lead to environmental protection.

1. Electoral reforms. In 1995, the Commission on Political Reform proposed to limit the number of lists by party and made the movements and parties accountable through a party plan. Then, the national debate was focused on strengthening political parties and ensuring minority representation. The results limited the number of lists per party, changed the formula by seat (Hare system) to the d'Hondt system, and included a minimum voting percentage to be elected.

\begin{tabular}{lcc} 
Table 6.2 & \multicolumn{2}{c}{ Nouse Elections, $1958-2002$} \\
\hline Number of Lists Registered for Senate and Hour & Senate & House \\
\hline 1958 & 67 & 83 \\
1960 & -7 & 113 \\
1962 & - & 143 \\
1964 & 147 & 192 \\
1966 & - & 215 \\
1968 & 206 & 221 \\
1970 & 176 & 316 \\
1974 & 210 & 253 \\
1978 & 225 & 308 \\
1982 & 202 & 343 \\
1986 & 213 & 330 \\
1990 & 143 & 351 \\
1991 & 251 & 486 \\
1994 & 319 & 628 \\
1998 & 322 & 692 \\
2002 & & 883
\end{tabular}




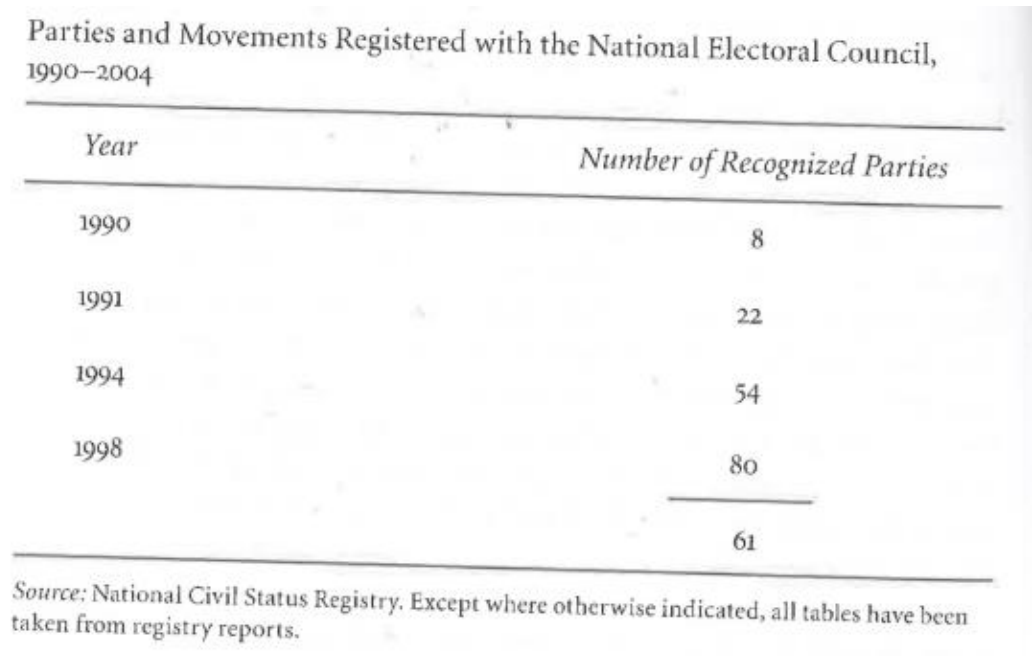

The proposal stopped the parties' elites controlling the candidates on the list. Also, the d' Hondt method produced party cohesion and included minorities. Lastly, at the house of representatives' balance was introduced regarding the national influence by the electoral threshold and minimum voter barriers (Pizarro, 2001). However, the clientelist and patronage system as a cultural practice had a tremendous influence during the decade. Therefore, the elites' cleavages continue, and the effects of the reform were not huge. The following graphic of Shugart, Moreno and Fajardo (2007) show the impact of the electoral reform for the decade. The graphic suggest that the strongest traditional parties adapted themselves to the electoral reform and were able to redistribute forces in the new electoral system.

\begin{tabular}{|c|c|c|c|c|c|c|c|}
\hline \multirow[b]{2}{*}{ Year } & \multirow[b]{2}{*}{ Party* } & \multicolumn{3}{|c|}{ Senate } & \multicolumn{3}{|c|}{ Mouse of Representatives } \\
\hline & & $\%$ Votes & 96 Seats & $A^{* *}$ & \% Votes & \% Seats & $A$ \\
\hline \multirow[t]{3}{*}{1990} & Liberal & 58.6 & 57.9 & $0.99^{-}$ & 59.2 & 59.8 & 1.01 \\
\hline & Conservative & 33.2 & 34.2 & 1.03 & 33.3 & 32.7 & 0.98 \\
\hline & Independent & 8.2 & 7.9 & 0.96 & 7.5 & 7.5 & 1.00 \\
\hline \multirow[t]{3}{*}{1991} & Liberal & 51.5 & 56.0 & 1.09 & 50.6 & 54.0 & 1.07 \\
\hline & Conservative & 26.3 & 24.0 & 0.91 & 25.6 & 26.1 & 1.02 \\
\hline & Independent & 21.9 & 20.0 & 0.91 & 23.7 & 19.9 & 0.84 \\
\hline \multirow[t]{3}{*}{1994} & Liberal & 52.8 & 56.0 & 1.06 & 52.8 & $54 \cdot 7$ & 1.04 \\
\hline & Conservative & 27.6 & 29.0 & 1.05 & 26.4 & 30.4 & 1.15 \\
\hline & Independent & 20.0 & 25.0 & 0.75 & 20.8 & 14.9 & 0.72 \\
\hline \multirow[t]{3}{*}{1998} & Liberal & 47.3 & 48.0 & 1.01 & 49.4 & 54.0 & 1.09 \\
\hline & Conservative & 22.5 & 25.0 & 1.11 & 23.6 & 23.6 & 1.00 \\
\hline & Independent & 30.3 & 27.0 & 0.89 & 27.1 & 22.4 & 0.83 \\
\hline
\end{tabular}


2. Internal democratization of parties. Parties traditionally did not consult with their electors who were their candidates. The experience changed with the Liberal party, who in a unique opportunity ran primaries for the first time in Colombia history in 1990 and then in 1994. This started an internal democratization by the selection of the candidate through a popular referendum.

3. The statute of the opposition. The Constituent Assembly debates promoted protection for the opposition. Then the Constitution established that the legislation should provide minimum standards to protect political opponents to the government. The purpose of the statute of the opposition was to guarantee the access to mass media, information, rebuttal, and consultation. Also, it created a special legal agency to represent the rights of the opposition, some political minorities, and created horizontal accountability by autonomies agencies of control. Nevertheless, the actual legal change was not produced until 2017 (Londoño,1999).

4. Reforming the Congress. The Constitutional Assembly introduced a stronger balance check and restriction to the president. The principal restriction was under what specific circumstances the president was given legislative powers (known as the state of exception to respond to economic, social- environmental, or security crises). The rule purpose was to avoid the traditional party-executive negotiation, implemented during the national front period that allowed the executive to suppress the Congressional capabilities. The second relevant step was the modernization of the Congress by Law 5 of 1992 and the separation of the administrative functions.

5. The lobbyist activities remained without control or legislation. During the 1990s, the Congress gave some debates about limitations to financial support and accountability of who, how, and when groups of interest can put pressure or influences over Congressmen. These initiatives were unsuccessful, but the practice remains without regulation, as part of the clientelist, patronage and corruption system. 
Table 7.4

Votes-to-Scats Conversions for Traditional and Nontraditional Political

Forces in Colombia, 1990-1998

\begin{tabular}{|c|c|c|c|c|c|c|c|}
\hline \multirow[b]{2}{*}{ Year } & \multirow[b]{2}{*}{ Party } & \multicolumn{3}{|c|}{ Senate } & \multicolumn{3}{|c|}{ House of Representatives } \\
\hline & & 96 Votes & 96 Seats & $A^{* *}$ & \% Votes & 96 Seats & A \\
\hline \multirow[t]{3}{*}{1990} & Liberal & 58.6 & 57.9 & $0.99^{-}$ & 59.2 & 59.8 & 1.01 \\
\hline & Conservative & 33.2 & $34 \cdot 2$ & 1.03 & 33.3 & 32.7 & 0.98 \\
\hline & Independent & 8.2 & 7.9 & 0.96 & 7.5 & 7.5 & 1.00 \\
\hline \multirow[t]{3}{*}{1991} & Liberal & 51.5 & 56.0 & 1.09 & 50.6 & 54.0 & 1.07 \\
\hline & Comservative & 26.3 & 24.0 & 0.91 & 25.6 & 26.1 & 1.02 \\
\hline & Independent & 21.9 & 20.0 & 0.91 & 23.7 & 19.9 & 0.84 \\
\hline \multirow[t]{3}{*}{1994} & Liberal & 52.8 & 56.0 & 1.06 & 52.8 & 54.7 & 1.04 \\
\hline & Conservative & 27.6 & 29.0 & 1.05 & 26.4 & 30.4 & 1.15 \\
\hline & Independent & 20.0 & 25.0 & 0.75 & 20.8 & 14.9 & 0.72 \\
\hline \multirow[t]{3}{*}{1998} & Liberal & 47.3 & 48.0 & 1.01 & 49.4 & 54.0 & 1.09 \\
\hline & Comservative & 22.5 & 25.0 & 1.11 & 23.6 & 23.6 & 1.00 \\
\hline & Independent & 30.3 & 27.0 & 0.89 & 27.1 & 22.4 & 0.83 \\
\hline
\end{tabular}

Sounce: Adapted from Gutierrec Sanin (1998).

-The categories "I.iberal" and "Conservative" include various dissident movements within

those larger political forces (for instance, the National Salvation Movement, led by a

dissident Conservative).

- Advantage ratio, $A=(\%$ seats $) /(\%$ votes $)$

6. Campaign and financing. The constitution of 1991 looks for parties and candidates less dependent of legal or illegal economic powers. The Constitution try to increase transparency, accountability, to stop imbalances in the representation, and increase participation by giving equal access to state financial sources. The Law 130 of 1994 produce those changes. However, during the electoral time of Andres Pastrana in1994 and Ernesto Samper in 1998, more than the $50 \%$ of their campaigns came from drug-trafficking sources, which created a strong institutional crisis at the end of the decade. The Law 130 regulated the money flow, and the funds should go to a national fund and be distributed to organizations by percentage. Also, the law determined the number of seats in the Senate and House of Representatives that received funds and maximum money that can be expended in every electoral process. The system had been criticized because it gives privileges to the strongest parties, promotes more party fragmentation and does not create a treasurer per party (Pizarro \& Bejarano, 2007).

7. Tension between executive and legislative. The constitution creates a set of rules that distinguished their functions. The Congress has the obligation of legislate and only by exception, the executive legislates. Nevertheless, the senate can delegate in some matters to the president that competence. The negotiations between the Congress and the president during the 1990s relied on how the executive created political conditions to get back the delegation to legislate. The second debate was on the technical disparity. The executive has strong financial resources to include experts and support agencies to manage the information and take decisions. The Congress has no separated or independent agencies that make research or support the legislative process. The electoral process shows that if the president 
has a strong popular support, he can oppose the Congress, or he will depend on his abilities to control the majoritarian parties elected (Botero, 1997).

8. Post-colonialism. Post- colonialism in this context is understood as a form of cultural, political, and social constraints inherited from the colonial times where the Spanish created a political order based on land aristocrats' ownership and racism that designated people in certain social classes. It produced a control of the factors of production centralized in traditional families that remained in power since that time, with some inclusion of new elites. Therefore, for this research it is not possible to evaluate the whole post-colonial system, but the indicator of the concentration of land can allow to understand the remains of the colonialist system. For example, "in 1996, 52 \% of the land registered was privately owned, whereas in 1985 it was $89 \%$. By 1996, of the 98.3 million hectares of rural land registered, 32\% corresponded to indigenous and black lands, and $16 \%$ to state lands. In this year, the total land registered corresponded to $45 \%$ of the total surface of the Republic of Colombia, which is 114 million hectares." (del Pilar Rodriguez \& Cuervo, 2011).

\section{The environmental Colombian movement- relation with democratization process.}

The Colombian participation in the United Nations Conference on the Human environment of Stockholm in 1972, the energy crisis of 1973, and the internal mobilizations generated impact in the public universities of Tolima, Nacional-Palmira, and Valle. This produced a boom in the environmental movement in Colombia that joined with the pedestrian revindications. At the beginning, the principal goal was a sustainable and rational use of the environmental resourses. The Code for natural Resourses in 1972 was promulgated as a presidential initiative by Alfonso López (1974-1978). This was the result of the participation in the conference of Stockholm. The relevance of this antecedent is two elements. First, the western linkages, influence of international organizations in the domestic politics; and second, the clear antagonism of the industrial, elites cleaves with the environmental movement. Alfonso López went against the argument that environmental protection produces negative effect in the economic development of the country putting in risk his political capital, however he was supported by the international pressure (Becerra, 2009).

During the 80s and 90s, the social movements claim for changes in the land use and access to public services which promote creation of NGOs. The environmental movement initiated an organizational period with the emerge of important NGOs such as: Fundación Herencia Verde, la Fundación Mayda, La Corporación Ecológica y Cultural Penca de Sábila, los Grupos Ecológicos de 
Risaralda (FUNDAGER), la Fundación Enda América Latina, la Fundación Ecológica Autónoma (FEA), la Red de Agricultura Ecológica (RAE), la Corporación Artemisa, CETEC de Cali, la Fundación Ecológica Pro Sierra Nevada de Santa Marta, el Cabildo Verde de Villa de Leyva and others indigenous organizations in their territorial space.

Acuña (2003) classifies the environmental movement during the 90s in two periods. From the ECONGENTE conference (1983) until the Guaduas conference (1992). ECONGENTE was the first national Congress created by environmental organizations ${ }^{2}$, the participation of 70 environmental organization, plus other social actors. In 1992, the environmental movement to prepare Rio'92 created a national debate on the content of Rio, for instance implications of environmental principles and sustainable development. After Rio, Law 99 of 1993 was produced and the institutional structure was modified, the Ministry of the Environment and the National Environment System (SINA) were created. In addition, ECOFONDO as an NGO assigns environmental responsibility to civil society. The entity was created to allocate funds obtained from international sources to promote environmental projects. Its performance was controversial from the beginning due to the proliferation of NGOs, the strong relationship with the government and the influence of international organizations.

The main sources of ECOFONDO were the debt with nature and environmental action (FAN), which arise from the idea of the debt of the industrialized countries with nature. Part of the literature identifies the decade of the 90 s as the mobilization of resources and the institutionalization of the environmental movement. Some ecological parties were created, and others adopted environmental platforms. Another level of analysis can be observed due to the influence of green international movements at the domestic levels. The decade shows an increase in connectivity with international NGOs, those that supported the discourse, political platforms, provided funds and promoted a globalized promotion of environmental issues (Keck and Sikkink, 2014).

At the end of the decade 1998, the government held the national environmental conference, called the environmental agenda for the peace. At the end of the 1990s the intensification of the internal conflict was evident; the negotiation was closed between Pastrana government and FARC Guerrilla. This national conference declared the direct and indirect environmental cost for the whole society and the internal conflict increases environmental challenges.

The inclusion of environmental rights in the Constitution had been assessed as an important recognition of environmental concerns. The environmental constitution includes fifty-one articles on environmental protection, resource management and sustainable development. The government

\footnotetext{
${ }^{2}$ CERCO (Consejo Ecológico de la Región Centro Occidental de Colombia), FEA (Fundación Ecológica Autónoma) Primer Encuentro Nacional de Organizaciones Ecológicas realizado en Santander de Quilichao (Cauca)
} 
responds to Rio's commitments by producing a change in the legal framework and in the institutional structure. There was a coalition between bureaucrats and the participation of NGOs that influence policy change and the outcomes.

Evidence of this coalition was the strong opposition to the legislative procedure of Law 99 promoted by the ANDI organization of the industrials, also for both the oil and construction sector. However, the strong pressure of international organization, and the personalist power of the president were the key factors that allowed producing the outcome (Acuña, 2006). The memories of the first minister of environmental reconstruct the debates, elites and cleavages structures behind the promulgation of the Law 99, the creation of other institutions such as National Department Naturals Resources and environment (APROAMBIENTE 1990), indigenous territories and national parks like Amazon (FNA 2008).

One of the evidences of the linkage with western and the level of influence of the international organizations in this domestic change is that the Law 99 declared the adoption of the principles of the Declaration of Rio (Article 1). In addition, it includes principles such as precaution, reparation by the polluter, responsibility, and the integration of development and economic, social and environmental protection.

The institutional change granted a broad competence to the Ministry of the Environment. The Ministry acquires the competence to enact policies on health, agriculture, trade and international relations focused on environmental issues, and also determined the environmental plans that the economic sector should follow.

Other independent agencies of control and vigilance get environmental competence and it was created the Unit of environmental Policy at the National Department of Planning to ensure the inclusion of an environmental dimension in the instruments of economic policy as the national plan of development and the instruments promoted by the National Council of Social and Economic policy.

At the local level 34 Regional Autonomous Corporations (CAR) were created, which had the function of decentralizing, promoting autonomy and participation at the local level. Its main obligation is to manage, within the area of its jurisdiction, the environment and renewable natural resources. In addition, they have to promote the full sustainable development of the country. From scientific support, institutional change includes the creation of five technical research centers with the purpose of protecting, conserving and promoting the understanding of the environment and resources. They focus on endemic ecosystems, protected areas, the classification of areas and human impact. 
The relevance of the Ministry of the Environment does not last. Since 1998, the pendulum of progressive protection of the environment produced by the increase of democratization and the influence of international forces, began to decline. The return flow initiated by the reform of the mining code, will then be evidence through reforms to the oil sectors (2003-2013). The counterreform that removed the Ministry of Environment and the CAR from the licensee's procedure. This intervention aims to make environmental legislation in mining more flexible and promote the extraction of energy resources.

As for the political parties, the environmental claims were absorbed by the traditional parties, only one can be classified as a green party, it was the oxygen of the green party, led by Ingrit Betancourt, who was kidnapped by the FARC in 2002, after some of the environmental principles were adopted by the center-left Green Party, led by Antanas Mockus.

The armed conflict. The relevant implications of the internal conflict refer to impacts on ecosystems, the propagation of coca crops, monocultures. As a result, the environment had been highly contaminated as a result, for example, the pipelines were systematically used as targets for the guerrillas. In addition, even in democratic times, the environmental activist had been persecuted by armed groups, mostly on the right side, and with some complicity on the part of the state. To illustrate this point, I add some statistics from the García Peña-Jaramillo study (2007), where it is possible to evaluate the peace process, the agreements reached and the number of human rights violations and deaths. The environmental movement was aimed at the same level as a human rights activist. More research must be done to identify that the direct cause of death was environmental, for example, opposition to a mega energy project or participation in environmental activism. 


\begin{tabular}{|c|c|c|c|c|c|}
\hline $\begin{array}{l}\text { Acronym } \\
\text { in Spanish }\end{array}$ & $\begin{array}{l}\text { Name int } \\
\text { Spanish }\end{array}$ & $\begin{array}{l}\text { Name in } \\
\text { English }\end{array}$ & $\begin{array}{l}\text { Year } \\
\text { Founded }\end{array}$ & $\begin{array}{l}\text { Participation } \\
\text { in Peace Talks }\end{array}$ & $\begin{array}{l}\text { Date of } \\
\text { Demobilization/ } \\
\text { Current Status }\end{array}$ \\
\hline FARC & $\begin{array}{l}\text { Fuerzas } \\
\text { Armadas } \\
\text { Revoluionarias } \\
\text { de Columbia }\end{array}$ & $\begin{array}{l}\text { Revolutionary } \\
\text { Armed } \\
\text { Forces of } \\
\text { Colombia }\end{array}$ & 1964 & $\begin{array}{l}\text { Jan. } 1983-\text { Oct. } 1987 \\
\text { June 1991-Mar. } 1992^{*} \\
\text { July } 1998-\text { Feb. } 2002\end{array}$ & Still active \\
\hline ELN & $\begin{array}{l}\text { Ejército de } \\
\text { Liberación } \\
\text { Nacional }\end{array}$ & $\begin{array}{l}\text { National } \\
\text { Liberation } \\
\text { Army }\end{array}$ & 1964 & $\begin{array}{l}\text { June 1991-Mar. } 1992^{*} \\
\text { Sept. 1994-June 2002** }\end{array}$ & Still active \\
\hline EPL & $\begin{array}{l}\text { Ejército } \\
\text { Popular de } \\
\text { Liberación }\end{array}$ & $\begin{array}{l}\text { People's } \\
\text { Liberation } \\
\text { Army }\end{array}$ & 1967 & $\begin{array}{l}\text { July } 1983-\text { Dec. } 1985 \\
\text { Jan. } 1990-\text { Feb. } 1991 \\
\text { June } 1991-\text { Mar. } 1992^{*}\end{array}$ & $\begin{array}{l}80 \% \\
\text { demobilized in } \\
1991 \text {; remaining } \\
20 \% \text { still active }\end{array}$ \\
\hline Mrg & $\begin{array}{l}\text { Movimiento } \\
19 \text { de Abril }\end{array}$ & $\begin{array}{l}\text { 19th of April } \\
\text { Movement }\end{array}$ & 1974 & $\begin{array}{l}\text { July } 1983 \text {-June } 1985 \\
\text { Jan. 1989-Mar. } 1990\end{array}$ & $\begin{array}{l}\text { Demobilized in } \\
1990\end{array}$ \\
\hline PRT & $\begin{array}{l}\text { Partido } \\
\text { Revolucionario } \\
\text { de lo5 } \\
\text { Trabajadores }\end{array}$ & $\begin{array}{l}\text { Revolutionary } \\
\text { Worker's } \\
\text { Party }\end{array}$ & $\begin{array}{l}1984 \\
\text { (broke } \\
\text { off of } \\
\text { EPL) }\end{array}$ & Apr. 1990-Jan. 1991 & $\begin{array}{l}\text { Demobilized in } \\
1991\end{array}$ \\
\hline MAQL & $\begin{array}{l}\text { Movimiento } \\
\text { Armado } \\
\text { Quintín Lame }\end{array}$ & $\begin{array}{l}\text { Quintin Lame } \\
\text { Armed } \\
\text { Movement }\end{array}$ & 1984 & June $1990-A p r .1991$ & $\begin{array}{l}\text { Demobilized in } \\
1991\end{array}$ \\
\hline $\mathrm{CGSB}^{*}$ & $\begin{array}{l}\text { Coordinadora } \\
\text { Guerrillera } \\
\text { Simón Bolivar }\end{array}$ & $\begin{array}{l}\text { Simon Bolivar } \\
\text { Guerrilla } \\
\text { Coordinator }\end{array}$ & 1987 & June $1991-$ Mar. $1992^{*}$ & $\begin{array}{l}\text { Disbanded in } \\
1993\end{array}$ \\
\hline CRS & $\begin{array}{l}\text { Corriente de } \\
\text { Renovación } \\
\text { Socialista }\end{array}$ & $\begin{array}{l}\text { Current of } \\
\text { Socialist } \\
\text { Renovation }\end{array}$ & $\begin{array}{l}1991 \\
\text { (broke } \\
\text { off from } \\
\text { ELN) }\end{array}$ & Nov. $1993-$ Mar. 1994 & $\begin{array}{l}\text { Demobilized in } \\
1994\end{array}$ \\
\hline $\mathrm{AUC}^{* * *}$ & $\begin{array}{l}\text { Autodefensas } \\
\text { Unidas de } \\
\text { Colombia }\end{array}$ & $\begin{array}{l}\text { United Self- } \\
\text { Defense Groups } \\
\text { of Colombia }\end{array}$ & 1996 & Does not apply & Still active \\
\hline
\end{tabular}

The CG5B was an umbrella organization that was formed in 1987 by FARC, ELN, EPL, M19, PRT, and MAQL, but by the time it held talks with the government in Caracas in 1991 and Tlaxcala in 1992 it was reduced to the FARC, the EIN, and a smail remnant of the EPL.

*Although constantly interrupted by suspension and long pauses, formal and informal talks and contacts were held with the ELN during almost all of the Samper and Pastrana administrations.

**A Although the Uribe administration is currently undergoing talks with the AUC, it has not yet recognized them as a political actor, nor have any of the administrations analyzed in this chapter. 
Significant Peace Accords Signed, 1984-2002

\begin{tabular}{|c|c|c|}
\hline Name (and Place) & Date & Parties \\
\hline La Uribe Accord (La Uribe, Meta) & Mar. 28, 1984 & Betancur government, FARC \\
\hline Corinto Accord (Corinto, Valle) & Aug. 23,1984 & Betancur government, $M_{19}$ \\
\hline El Hobo Accord (El Hobo, Huila) & Aug. 24, 1984 & Betancur government, EPL \\
\hline Final Peace Accord (Santo Domingo, Cauca) & Mar. 9, 1990 & Barco government, $\mathrm{M} 19$ \\
\hline Final Peace Accord (Ovejas, Sucre) & Jan. 25, 2991 & Gaviria government, PRT \\
\hline Final Peace Accord (Bogotá, DC) & Feb. 15, 1991 & Gaviria government, EPL \\
\hline Accord on the Agenda (Caracas, Venezuela) & June 6, 1991 & Gaviria government, CGSB \\
\hline Final Peace Accord (Bogotá, DC) & June 26, 1991 & Gaviria government, MAQL \\
\hline Final Peace Accord (Flor del Monte, Sucre) & Apr. 9, 1994 & Gaviria government, CRS \\
\hline Draft Accord of Viana (Madrid, Spain) & Feb. 9, 1998 & Samper government, ELN* \\
\hline Gates of Heaven Accord (Mainz, Germany) & July 15, 1998 & delegates civil society, EL.N \\
\hline $\begin{array}{l}\text { Agenda for Change for Peace } \\
\text { (Caquetania, Caquet } 6 \text { ) }\end{array}$ & May 6, 1999 & Pastrana government, FARC \\
\hline $\begin{array}{l}\text { Roles for the Encounter Zone } \\
\text { (Havana, Cuba) }\end{array}$ & Dec. 14,2000 & Pastrana government, ELN \\
\hline $\begin{array}{l}\text { Los Pozos Accord (San Vicente } \\
\text { del Caguán, Caquetá) }\end{array}$ & Feb. 9, 2001 & Pastrana government, FARC \\
\hline Accord on Humanitarian Exchange & June 2,2001 & Pastrana government, FARC \\
\hline $\begin{array}{l}\text { San Francisco de la Sombra Accord } \\
\text { (San Vicente del Caguán, Caquetá) }\end{array}$ & Oct. 5, 2001 & Pastrana government, FARC \\
\hline Accord for Colombia (Havana, Cuba) & Nov. 24, 2001 & Pastrana government, ELN \\
\hline
\end{tabular}

*Never ratified by ELN Central Command.

Evolution of the Human Rights Situation and Sociopolitical Violence in Colombia, 1980-2003

\begin{tabular}{|c|c|c|c|c|c|c|c|c|c|c|c|c|}
\hline & 1 & 2 & 3 & 4 & 5 & 6 & 7 & 8 & 9 & 10 & II & 12 \\
\hline Ycat & $\begin{array}{c}\text { Extrajudicial } \\
\text { executions and } \\
\text { pointical } \\
\text { homicides }\end{array}$ & $\begin{array}{l}\text { Forced dit- } \\
\text { appouminces }\end{array}$ & $\begin{array}{l}\text { Extmpiudicial } \\
\text { executions anal } \\
\text { homicides } \\
\text { of seciaily } \\
\text { marginedized } \\
\text { pernons } \\
\text { (a) }\end{array}$ & $\begin{array}{c}\text { Subtotal of } \\
\text { victims } \\
4=1+2+3\end{array}$ & $\begin{array}{c}\text { Deaths in } \\
\text { combat and } \\
\text { crossfice }\end{array}$ & $\begin{array}{l}\text { Victims of } \\
\text { seclapowiticni } \\
\text { violence: dend } \\
\text { end nissing } \\
6=4+5\end{array}$ & $\begin{array}{l}\text { Daily avenage } \\
\text { of socio- } \\
\text { pointical dend } \\
\text { and missing } \\
\quad 7=6+365\end{array}$ & $\begin{array}{c}\text { Total } \\
\text { honvicides in } \\
\text { conuman crimie }\end{array}$ & 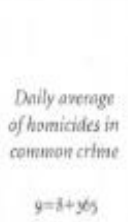 & $\begin{array}{l}\text { Totai vioient } \\
\text { draths } \\
\text { (b) } \\
10=6+8\end{array}$ & $\begin{array}{c}\text { Total daily } \\
\text { averoge of } \\
\text { violent deuths } \\
10-10+96\end{array}$ & $\begin{array}{l}\text { Total victims } \\
\text { of socio- } \\
\text { political } \\
\text { violence + } \\
\text { retel vioient } \\
\text { deaths } \\
\text { 12: } 6: 10\end{array}$ \\
\hline 1980 & 92 & 4 & & 96 & $u$ & 17 & 0.32 & 9,005 & 24.67 & 9,122 & 24.99 & $1.28 \%$ \\
\hline 1981 & 269 & $10 t$ & & 370 & 95 & 465 & 1.27 & 10,248 & 28.08 & 10,713 & 29,35 & $434 \%$ \\
\hline 1982 & 525 & 170 & & 655 & 69 & 724 & 1.98 & 9,856 & 27.00 & 10,580 & 28.59 & $684 \%$ \\
\hline 198 & 594 & 109 & & 703 & 173 & 876 & 240 & 8,845 & 24.23 & 9721 & 26.63 & $9.01 \%$ \\
\hline 1984 & 542 & 122 & & 664 & 225 & 889 & 2.44 & 9,805 & 26.86 & 10,694 & 2930 & 8.3196 \\
\hline 1985 & 630 & 82 & & 712 & 386 & 1,098 & 3.01 & 11,801 & 32.33 & 12,899 & 3534 & $8.51 \%$ \\
\hline 1986 & 1,387 & 191 & & $157^{8}$ & 362 & 1,940 & 5.32 & 13.732 & 37.62 & 15,672 & 42.94 & $12.38 \%$ \\
\hline 1987 & 1,651 & 109 & & 1,760 & 313 & 2,073 & 5.68 & 15346 & 4204 & 17,419 & 40.72 & $10.90 \%$ \\
\hline 1988 & 2,738 & 210 & 273 & 3,221 & 1,083 & 4,304 & 11.79 & 16,796 & 46.02 & 21,100 & 57.81 & $20.40 \%$ \\
\hline 1989 & 1,976 & 137 & 364 & 2,479 & 7,32 & 3,211 & 8.80 & 20,101 & 55.07 & 23312 & 63.87 & $13.77 \%$ \\
\hline 1990 & 2,007 & 217 & 267 & 2,491 & 1,229 & 3720 & 10.19 & 21,600 & 59.18 & 25320 & 69.37 & $14.69 \%$ \\
\hline 1991 & 1,829 & 180 & 359 & 2.398 & 1,364 & 3.762 & 10.3 & 25,110 & 68.79 & 28,8772 & 79.10 & $1303 \%$ \\
\hline 1992 & $2,1 / 8$ & 191 & sos & 2,874 & 1,602 & 4,476 & 12.26 & 25,125 & 68.84 & 29,601 & 80.10 & $15.12 \%$ \\
\hline 1993 & 2,190 & 144 & 16! & 2,495 & 1,097 & 3.592 & 9.84 & 24,042 & 65.87 & 27,634 & $75-71$ & $1,00 \%$ \\
\hline 1994 & 1,668 & 147 & 277 & 2,092 & 1,009 & 3,101 & 8.50 & 23.543 & 64.50 & 26,644 & 73.00 & $11.64 \%$ \\
\hline 1995 & ${ }_{1} 8332$ & 85 & 371 & 2,287 & 1,049 & 3,336 & 9.14 & 22,062 & 60.44 & 25,398 & 69.58 & $1313 \%$ \\
\hline 2996 & 1,479 & 168 & 169 & 1,816 & 1,131 & 2,947 & 6.07 & 23,695 & 64.92 & 26,642 & 72.99 & 1. $06 \%$ \\
\hline 1997 & 2,199 & 223 & 143 & 2,564 & 1.283 & 3.897 & 20.54 & 21,552 & 58.99 & 25,379 & 69.53 & $5-16 \%$ \\
\hline
\end{tabular}




\begin{tabular}{|c|c|c|c|c|c|c|c|c|c|c|c|c|}
\hline & 1 & $\pi$ & 3 & 4 & 5 & 6 & 7 & 8 & 9 & wo & " & 12 \\
\hline Year & 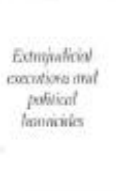 & 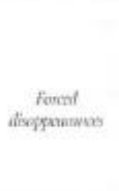 & 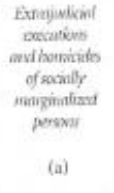 & $\begin{array}{l}\text { Sidnond of } \\
\text { viaims } \\
f=3+24\}\end{array}$ & 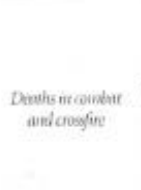 & 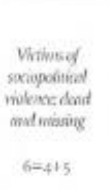 & 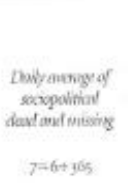 & 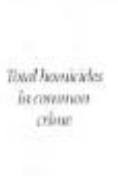 & 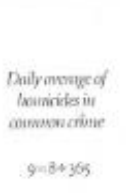 & $\begin{array}{l}\text { Toud' vivent } \\
\text { douthe } \\
\text { (b) } \\
x=6+8\end{array}$ & 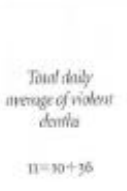 & 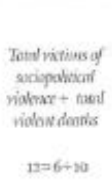 \\
\hline 1998 & 1,812 & 260 & 150 & 2,2222 & 1,463 & 3,685 & 10.10 & 19,411 & 59.18 & 23,096 & 63.28 & $15.96 \%$ \\
\hline 1099 & 2,298 & 340 & 244 & 2,882 & 1,479 & $43^{61}$ & 1. .95 & 20,087 & 55.63 & $24,44^{8}$ & 66.98 & $178.4 \%$ \\
\hline 2000 & 3,901 & 629 & 321 & 4,851 & 5730 & 6,581 & 18.03. & 19,959 & 54.68 & $26.54^{\circ}$ & 72.71 & $2480 \%$ \\
\hline 2001 & 3,854 & 494 & 256 & 4,604 & 1,965 & 6.569 & 18.00 & 21,271 & 51.23 & 27,840 & 76.27 & $23.50 \%$ \\
\hline 2002 & $3.5 \times 6$ & 462 & 357 & 4,355 & 3.420 & 7805 & 21.38 & 21,032 & 57.62 & 28,837 & 79.01 & $27.07 \%$ \\
\hline 2003 & 3.231 & 421 & 299 & 3911 & 2,430 & 6,341 & 17,37 & 23.523 & 64.45 & 29,864 & 81.82 & $21.23 \%$ \\
\hline Total & 44,419 & 5,155 & 4536 & 54,100 & 25,710 & 79,820 & & 437,527 & & $517,3,47$ & & \\
\hline $\begin{array}{l}\text { Sources } \\
\text { CINEP } \\
\text { Human } \\
\text { Violent } \\
\text { Revista } \\
\text { Torres } \\
\text { Giralde } \\
\text { Permar } \\
\text { The ne: } \\
\text { Sucre, } \\
\text { The ma } \\
\text { Writter } \\
\text { Notes } \\
\text { a. Due } \\
\text { b. Tota }\end{array}$ & 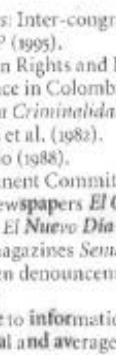 & $\begin{array}{l}\text { egational Just } \\
\text { Politicat Viole } \\
\text { ia, Bogoth, BC } \\
\text { d (Criminalit } \\
\text { tee for the De } \\
\text { Colombiano, } \\
\text { de Ibague, EI } \\
\text { and, Coabbio, } \\
\text { uents in the fil } \\
\text { ant problems, } \\
\text { daily violent }\end{array}$ & $\begin{array}{l}\text { ice and Peace } \\
\text { nce Databise } \\
\text { TP, nos. I to } \\
\text { Review), Bo } \\
\text { fense of Hum } \\
\text { Espectador, } \\
\text { Pisis, El Univer } \\
\text { and Cromos. } \\
\text { es of the Colo } \\
\text { lata on homic } \\
\text { deaths do not }\end{array}$ & 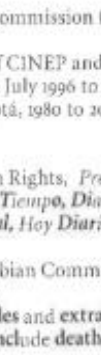 & 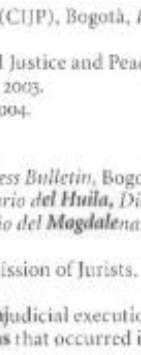 & 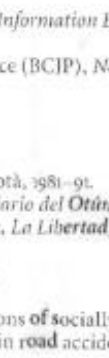 & $\begin{array}{l}\text { Bulletin, vols. } 11 \\
\text { uchey Niebla (1) } \\
\text { Diario del Sit } \\
\text { La Nación, Ln } \\
\text { y marginalized } \\
\text { ents. }\end{array}$ & $\begin{array}{l}\text { to } 8 . \\
\text { Night and Fog } \\
\text { Opinibn, La } \\
\text { per Herido, } \\
\text { persons befor }\end{array}$ & $\begin{array}{l}\text { Review), Panc } \\
\text { El Liberni, ElM } \\
\text { Tande, and Van } \\
\text { re } 1988 \text { are not: }\end{array}$ & $\begin{array}{l}\text { rama of Hur } \\
\text { Eridiano de } \\
\text { guardiar Liber } \\
\text { ncluded. }\end{array}$ & $\begin{array}{l}\text { Ian Rights and } \\
\text { Utdoba, ElMer: } \\
\text { ai. }\end{array}$ & Political \\
\hline
\end{tabular}

\section{Findings}

Authoritarian regimes are less likely to protect environment for the following reasons: lack of accountability, power concentrated in elites' association with economic activities that degrade the environment, restrictions in civil participation in the decision-making process, and the lack of information traffic and coercion do not allow promotion of environmental prevention and conservation.

Scholars disagree on authoritarian characteristics in Colombia rule, considering the prevalence of a military regime (40s decade), party prevalence of National Front period (Frente Nacional period), structural determinants of the regime type like economic growth that identified it as second wave of democratization (Huntington). Also, historical institutionalism (Bejarano, 2011) identified Colombia as a precarious democracy. This research suggest that it is an authoritarian regime that started a legal and institutional process of democratization in the 1990s. Thus, the process is a pendulum that goes in double flow, a first tendency to progress, and a flowback that represses and leads to new forms of authoritarianism.

The relationship among democracy and environmental public policy improvement can be explained by the regime type. The parties' system, the relation of the executive and legislative branch, the participation of green parties, elites' cleavages, the civil society participation, and the influence of International forces (NGOs, International Organizations, Multilateral System) exposed the 
relationship between democracy and environmental public policy improvement. Considering the historical and institutional factors, the identification of the causal mechanism conditions existed and they explained the changes during the 1990s decade.

\section{Conclusion}

During the 1990s decade, the democratization process in Colombia has a positive influence in the environmental policy outcome. The findings produced in case of study are that an increase of democratization process has a positive influence on the environmental protection. Under certain conditions of internal and external factors, it is more likely that a positive change in the policy outcome that leads to an increase of environmental protection can be done. The present research contributes to first, the theoretical debate of competitive authoritarianism and contentious politics apply to Latin-American cases. Second, the research integrates political science methodological and theoretical framework with international relations theory and public administration.

This study allows to understand which new authorities are responsible for environmental protection, the changes in the composition of the political forces that participated in the production of the legal and administrative changes, including the participation of environmental movement and the influence of the international environmental conferences. Also, the findings are that both domestic and international pressures influence on the regime characteristics and the civil society. The result is that it produced an increase on environmental protection.

The strong democratization process is identified during the 1990s decade because of the institutional, legal, and constitutional change, peace process, political and electoral reform, and the advance in institutionalization of the environmental protections.

More study on authoritarian heritage needs to be done, practices as the manipulation of the elections after the period known as "Frente Nacional" (national front regime) where the Liberal and Conservative parties' stop peace process, supported a framework based on patronage, elites' cleavages, the exclusion of third political forces, and keep the control of the state apparatus after the 1990s. Besides, this is intertwined with a social construction where the value of life is minimum and were clientelist and patronage skip the legal or institutional controls.

This research has a limitation to include new perspectives. There is a need of alternative explanations that came from constructivist perspective that analyses the relationship of democracycivil society and policy outcomes in environmental and energy areas by using mixed methods. This will allow to run data sets to measure the impact of democracy in public policy outcomes focused on common goods as environment or energy resourses. 


\section{References}

Acuña, I. T (2006). La política ambiental en los planes de desarrollo en Colombia 1990-2006. Una visión crítica. Revista Luna Azul, (22).

Acuña, I. T. (2003). El movimiento ambiental colombiano, una aproximación a su historia reciente. Ecología política, (26), 107-119.

Becerra, M. R. (2009). ¿Hacer más verde al Estado colombiano?. Revista de estudios sociales, (32), 18-33.

Beckerman, W. (1992). Economic growth and the environment: Whose growth? Whose environment?. World development, 20(4), 481-496.

Bejarano, A. M. (2011). Precarious Democracies: Understanding Regime Stability and Change in Colombia and Venezuela. ND Kellogg Inst Intkl Studies. University of Notre Dame Press.

Bejarano, A. M. (2011). Precarious Democracies: Understanding Regime Stability and Change in Colombia and Venezuela. ND Kellogg Inst Intkl Studies. University of Notre Dame Press.

Bejarano, A. M., \& Pizarro Leongómez, E. (2002). From" restricted" to" besieged": The Changing Nature of the Limits to Democracy in Colombia.

Bhattarai, M., \& Hammig, M. (2001). Institutions and the environmental Kuznets curve for deforestation: a crosscountry analysis for Latin America, Africa and Asia. World development, 29(6), 995-1010.

Botero, F. (1997). El Senado que nunca fue. La circunscripción nacional después de tres elecciones. Elecciones y democracia en Colombia, 1998, 285-337.

Brooker, P. (2013). Non-democratic regimes. Macmillan International Higher Education.

Carter, N. (2018). The politics of the environment: Ideas, activism, policy. Cambridge University Press.

Carter, N. (2018). The politics of the environment: Ideas, activism, policy. Cambridge University Press.

Cohen, Y. (1985). The impact of bureaucratic-authoritarian rule on economic growth. Comparative Political Studies, 18(1), 123-136.

Cohen, Y. (1985). The impact of bureaucratic-authoritarian rule on economic growth. Comparative Political Studies, 18(1), 123-136.

Dahl, R. (1971). Polyarchy, New Haven. Google Scholar.

del Pilar Rodríguez, D., \& Cuervo, E. C. (2011). Concentración de la tierra en Colombia. Comunicaciones en estadística, 4(1), 29-42.

Desai, U. (Ed.). (1998). Ecological policy and politics in developing countries: Economic growth, democracy, and environment. SUNY Press. 
Didia, D. O. (1997). Democracy, political instability and tropical deforestation. Global Environmental Change, 7(1), 63-76.

Doyle, M. W. (2005). Three pillars of the liberal peace. American Political Science Review, 463-466.

Dryzek, J. S. (1987). Rational ecology: environment and political economy.

Farzin, Y. H., \& Bond, C. A. (2006). Democracy and environmental quality. Journal of Development Economics, 81(1), 213-235.

Figures

Garcia-Peña Jaramillo, D. (2007). Colombia: In search of a new model for conflict resolution (pp. 91131). Notre Dame: University of Notre Dame Press.

Geddes, B. (2003). Paradigms and sand castles: Theory building and research design in comparative politics. University of Michigan Press.

Grossman, G. M., \& Krueger, A. B. (1991). Environmental impacts of a North American free trade agreement (No. w3914). National Bureau of Economic Research.

Hall, P. A., \& Taylor, R. C. (1996). Political science and the three new institutionalisms. Political studies, 44(5), 936-957.

Hartlyn, J. (1984). Military governments and the transition to civilian rule: The Colombian experience of 1957-1958. Journal of Interamerican Studies and World Affairs, 26(2), 245281.

Hartlyn, J. (1984). Military governments and the transition to civilian rule: The Colombian experience of 1957-1958. Journal of Interamerican Studies and World Affairs, 26(2), 245281.

Heilbroner, R. L. (1974). The Clouded Crystal Ball. The American Economic Review, 64(2), 121-124.

Keck, M. E., \& Sikkink, K. (2014). Activists beyond borders: Advocacy networks in international politics. Cornell University Press.

Li, Q., \& Reuveny, R. (2006). Democracy and environmental degradation. International studies quarterly, 50(4), 935-956.

Linz, J. J. (1975). Totalitarian and Authoritarian Regimes. Fred Greenstein and Nelson Polsby (eds.), Handbook of Political Science, Vol. 3.

Londoño, J. A. D. (2009). Estado Social de Derecho y neoliberalismo en Colombia: estudio del cambio social a finales del siglo XX. Revista de antropología y sociología VIRAJES, (11), 205228.

Londoño, J. H. (1999). Sistema de partidos y regimen electoral la gobernabilidad contra la democracia en la propuesta de reforma politica. Pensamiento Jurídico, (11). 
Mainwaring, S., \& Pérez-Liñán, A. (2013). Democracies and dictatorships in Latin America: emergence, survival, and fall. Cambridge University Press.

Mainwaring, S., \& Pérez-Liñán, A. (2013). Democracies and dictatorships in Latin America: emergence, survival, and fall. Cambridge University Press.

Midlarsky, M. I. (1998). Democracy and the environment: an empirical assessment. Journal of Peace Research, 35(3), 341-361.

O'donnell, G. (1978). Reflections on the patterns of change in the bureaucratic-authoritarian state. Latin American Research Review, 13(1), 3-38.

Ophuls, W. (1977). Ecology and the Politics of Scarcity. WH Freeman.

Paehlke, R. (1995). Environmental values for a sustainable society: the democratic challenge. In Greening Environmental Policy (pp. 129-144). Palgrave Macmillan, New York.

Pizarro Leongómez, E. (2002). Atomización partidista en Colombia: el fenómeno de las microempresas electorales.

Pizarro, E., \& Bejarano, A. M. (2007). Political Reform after 1991: What Still Needs to be reformed?. Peace, Democracy and Human Rights in Colombia, Notre Dame: Notre Dame University.

Remmer, K. L., \& Merkx, G. W. (1982). Bureaucratic-authoritarianism revisited. Latin American Research Review, 17(2), 3-40.

Sanz Giraldo, M. A. (2017). Las fronteras culturales de la Ley General Forestal: diferentes concepciones de naturaleza (Doctoral dissertation, Universidad del Rosario).

Schmitter, P. C., \& Karl, T. L. (1991). What democracy is... and is not. Journal of democracy, 2(3), 7588.

Smith, G. (2003). Deliberative democracy and the environment. Routledge.

Stevens, D., Bishin, B. G., \& Barr, R. R. (2006). Authoritarian attitudes, democracy, and policy preferences among Latin American elites. American Journal of Political Science, 50(3), 606620.

Stevens, D., Bishin, B. G., \& Barr, R. R. (2006). Authoritarian attitudes, democracy, and policy preferences among Latin American elites. American Journal of Political Science, 50(3), 606620.

Taylor, F. W. (2004). Scientific management. Routledge.

Van Der Heijden, H. A. (1997). Political opportunity structure and the institutionalization of the environmental movement. Environmental politics, 6(4), 25-50.

Velandia, C. (2018) Figure 1 and 2. Regime type argument. Method. Created with https://creately.com/app/?tempID=gc7qvpsj1\&login_type=demo\# 
Webster, S., \& Felton, M. (1993). Targeting for nature conservation in agricultural policy. Land Use Policy, 10(1), 67-82.

Wills-Otero, L. (2015). Latin american traditional parties, 1978-2006. Electoral trajectories and internal party politics. Ediciones Uniandes-Universidad de los Andes.

Wills-Otero, L. (2016). The electoral performance of Latin American traditional parties, 1978-2006: Does the internal structure matter?. Party Politics, 22(6), 758-772.

Winslow, M. (2005). Is democracy good for the environment?. Journal of Environmental Planning and Management, 48(5), 771-783.

Zakaria, F. (1997). The rise of illiberal democracy. Foreign Aff., 76, 22. 